\title{
若材齢における乾燥がセメント硬化体の 内部組織構造に及ぼす影響
}

\author{
伊代田岳史 ${ }^{1} \cdot$ 魚本健人 ${ }^{2}$ \\ 1 学生会員 東京大学大学院（T153-8505 東京都目黒区駒場 4-6-1） \\ 2 正会員 工博 東京大学生産技術研究所 教授（广153-8505 東京都目黒区駒場 4-6-1）
}

\begin{abstract}
コンクリートの養生は水和反応の促進のために適切な温度と湿度を保持する必要がある. しかし, 現 場においては型枠転用や工期短縮などを理由に早期脱型されることが多く，コンクリートが若材齢から 外部環境の影響を受けることがある. 本研究では若材齢時における乾燥と配合の影響がセメント硬化体 の水和反応, 内部組織構造, 圧縮強度にどの程度の影響を与えるかを定量的に評価した. その結果, 乾 燥の影響により水和反応は一時的に停止し内部組織構造が粗になることが定量評価できた. また水和が 一時停止した硬化体に再び水分供給すると再水和反応が起こり緻密化することも分かった. しかし, 圧 縮強度はほとんど発現せず，その理由が反応の形態と内部組織構造によるものであることを明示できた.
\end{abstract}

Key Words: curing, humidity, drying condition, cement hydration, porosity, re-supplying water

\section{1. はじめに}

コンクリート構造物は打設されてから脱型し, 供用を開 始する間に様々な環境の作用を受ける. 特に若材齢におい て受ける環境の作用はコンクリート内部の組織構造が未 だ構築されていないため, 後の強度や耐久性等の性質に大 きな影響を及ぼすものと考えられる.このため現行の示方 書等 ${ }^{1)}$ では若材齢期間においては養生を行い, セメントの 水和反応を促進させ所定の強度や耐久性を得る必要があ るとされている. 適切な養生の条件とは1適切な温度の確 保, (2湿潤状態の保持, (3)有害な作用からの保護, (4)過大 荷重からの保護などがあげられる.この中で適切な温度確 保のためには水和発熱の抑制のための配合や材料の選定, 養生期間中の温度管理等を行う必要があり, また湿潤状態 を保持するためには適切な水分を確保する必要があるた め配合上の内部水分量や養生期間中の乾燥の防止などを 考慮する必要がある.

このようにセメントの水和反応等を考えると養生時に おける環境条件は非常に重要であると考えられるが, 実際 の現場においては比較的軽視されがちである. その例とし て, 実現場においては型枠の転用や工期の短縮と行った理 由から早期脱型してしまうことが多く, 十分な養生環境が 確保できているとは言い難い. このような不十分な養生に より強度や耐久性が著しく低下しているといった報告 ${ }^{2)}$ されている. 早期脱型による養生不足は若材齢からコンク リートを外部環境にさらすこととなる. そのため, 周囲の
温度や乾燥の影響によりコンクリートの表面から水分が 逸散し, 内部の水分が不足してしまうことにより水和阻害 を受けることも考えられる. 一方でこのように水和阻害を 受けたコンクリートが周囲の湿度上昇や雨水, 再養生など といった構造物が供用されてから水分の供給を受けるこ とも考えられる.

このようにコンクリート構造物を考えた場合, 打設直後 から様々な環境作用の影響を受けており, それぞれの環境 条件により長期的に異なった性質を持つコンクリートに なりうる可能性がある. このような考え方からコンクリー 卜構造物の性能に対して支配的であるセメントの水和反 応に着目した場合, 外部環境である温度と湿度の影響を調 査することは非常に大切なことである. 従来から環境温度 が水和反応速度, 水和生成物一与える影響に関した研究 ${ }^{3)}$ は数多く行われているが, 環境湿度や初期材路時における 乾燥の影響が水和反応や内部組織構造に与える影響に関 した研究は少ない ${ }^{4)}$. また, 一度乾燥を受けたセメント硬 化体が再度水分の供給を受けた場合の水和挙動を研究し た例として佐伯ら ${ }^{5}$ の研究が挙げられるが, 早期脱型直後 からの連続的な乾燥とその後の水分供給の期間を短期間 としている. また水分供給後の内部組織構造等を検討して いる研究はほとんどみられない.

そこで本研究では配合上保持している水分を考慮して 水セメント比ごとに早期脱型による乾燥と連続的な湿潤 養生を行ったセメント硬化体の水和反応と内部組織構造 の違いを実験的に評価することを第一の目的とした. また， 
その上で一度乾燥の履歴を受けたセメント硬化体に再度 水分が供給された場合の水和反応と内部組織構造, 強度発 現特性を評価した. このような配合条件や養生条件の相違 による水和の特性を明らかにし，それに伴う空隙組織構造 の形成機構を把握することは, 多様化するコンクリートの 示す諸挙動を予測する上で非常に重要なことである.

\section{2. 実験概要}

\section{（1）实験要因と工程}

本研究においては普通ポルトランドセメントを用いた セメントペーストにより実験を行った. 供試体の大きさは 盖生環境の影響を一様に受けるように 20×20×80 $\mathrm{mm}$ の角 柱を用いて行った.なお，圧縮試験に関しては $150 \times 100 \mathrm{~mm}$ の円柱供試体を用いた. 実験は表-1 に示したが, 要因ごと に以下の三種類に分けて行った.

シリーズ 1 : 配合の違いによる湿潤養生と乾燥養生の比較

配合上含有する水分量を変化させるために水セメント 比を $0.25,0.30,0.35,0.40,0.50$ と変化させた試験体における湿 潤養生 W（水中養生）と連続乾燥養生 D（乾燥環境 RH50\%）による水和挙動之内部組織構造の把握 ${ }^{\text {() }}$

\section{シリーズ 2: 脱型時期と養生環境の違いによる比較}

水セメント比を 0.35 一定とし脱型時期（6,12,24 時間,5 日）と養生時の外部環境（真空, RH $50 \%, \mathrm{RH} 80 \%, \mathrm{RH} 100 \%$, 封縅水中) を变化させたときの水和挙動と内部組織構造の 把握 ${ }^{7}$

\section{シリーズ 3: 乾燥を受けた硬化体の水分再供給後の挙動}

水セメント比を $0.25,0.35,0.50$ の 3 種類として養生条件を (1)連続水中養生(W), (2)RH50\%環境下での連続乾燥養生(D), (3)打設から材歯 28 日までRH $50 \%$ で養生した後水中養生に 移行した水分再供給（DW）の3 種類とした試験体それぞ れの水和挙動と内部組織構造, 強度発現性, 水和生成物の 把握 $7,8,9)$

全ての実験において打設したセメントペーストを打設 直後から脱型までの期間は温度 $20^{\circ} \mathrm{C}$, 水の出入りのないよ うに封縅養生を行い, 脱型後, 恒温恒湿槽で実現したそれ ぞれの環境下で測定材跘まで養生を行った. 本研究におい ては乾燥の影響のみを評価するため外部環境温度は一定 の $20^{\circ} \mathrm{C}$ とし. なお, 均一なセメントペーストを得るため に練り混せ時閒を通常より長く取り，低水セメント比では しめ固めを十分に行い, 高水セメント比では打設までの時 間を長く取ることでブリージングを極力抑えた.

\section{(2) 測定方法}

\section{a) 水和進行の測定}

測定材齢に達した時点で供試体の一部をアセトンに浸 し, 振動ミルで粉砕し粉末状にすることで水和停止させた.
水和停止させた試料は自由水の逸散温度(A)で約 24 時間乾 燥させ, 乾燥後デシケータ内で試料を泠ました後, 試料を $1.0 \mathrm{~g}$ 程度るつぼに取り結合水の逸散温度(B)で結合水を脱 水させた。試料が恒量になるまで強熱し，その質量を量り 逸散水量を求めた. 求めた逸散水量からセメント $1 \mathrm{~g}$ 当た りの結合水量を換算し, 同一試料で 2 回行った平均值を結 合水量として求めた. 水和進行はこの結合水量を用いて示 している. なお, 自由水の逸散温度(A)並びに結合水の逸 散温度(B)に関してはシリーズ 1,2 の実験では前者を $50^{\circ} \mathrm{C}$, 後者を $1000^{\circ} \mathrm{C}$ とし, シリーズ 3 の実験では前者を $40^{\circ} \mathrm{C}$, 後者を $600^{\circ} \mathrm{C}$ とした. ここで, 水分逸散温度を変化させた 理由として $100^{\circ} \mathrm{C}$ 以上の自由水逸散温度では水和生成物の 破壊およびひひ割れの発生のおそれがあること ${ }^{10,11}$, また 自由水逸散温度を $40^{\circ} \mathrm{C}$ に変更した理由として文献 ${ }^{12}$ を参 考に水和物の結合水の脱水を防ぐことを目的とした. また, $1000^{\circ} \mathrm{C}$ での結合水逸散温度では炭酸化による質量变動が 起こることなどを考慮し，これらを防ぎより览密な測定を 試みたためである. なお，試験データにおける若干の誤差 の主な理由は試験体間の誤差と考えられる.

\section{b）内部組䄾構造の測定}

水和進行の測定に用いた供試体を利用し，5mm 角程度 に切断した試料を作製し，アセトンに浸すことにより水和 を停止させた. その後, 自由水の逸散温度(A)で乾燥させ ることにより内部自由水を脱水させ, 水銀圧入式ポロシメ 一タで細孔径分布を測定した. なお, ポロシメータの細孔 半径測定範囲は $3.2 \mathrm{~nm} \sim 320 \mu \mathrm{m}$ で, 本研究ではこの範用の 空隙径を毛細管空隙と考えた.

\section{c）水和生成物の測定}

末水和鉱物と反応生成物との関係と養生の違いにより

表-1 実験要因

\begin{tabular}{|c|c|c|c|}
\hline & W/C & 脱型時期 & 外部環境 \\
\hline シリーズ1 & $\begin{array}{l}0.25 \\
0.30 \\
0.35 \\
0.40 \\
0.50 \\
\end{array}$ & $24 \mathrm{hrs}$ & $\begin{array}{c}\mathrm{D}(\mathrm{RH} 50 \%) \\
W\end{array}$ \\
\hline シリーズ2 & 0.35 & $\begin{array}{l}6 \mathrm{hrs} \\
12 \mathrm{hrs} \\
24 \mathrm{hrs} \\
5 \text { days }\end{array}$ & $\begin{array}{l}\text { Ric } \\
\text { RH } 50 \% \\
\text { RH } 85 \% \\
\text { RH100\% } \\
\text { 封 } \\
\text { W }\end{array}$ \\
\hline シリーズ3 & $\begin{array}{l}0.25 \\
0.35 \\
0.50\end{array}$ & $6 \mathrm{hrs}$ & $\begin{array}{c}\mathrm{D}(\mathrm{RH} 50 \%) \\
\text { DW } \\
\text { W }\end{array}$ \\
\hline 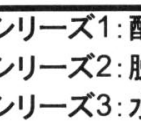 & 違期 & $\begin{array}{l}\text { 此較 } \\
\text { D違いに } \\
\text { 挙動 }\end{array}$ & 比較 \\
\hline
\end{tabular}


異なった反応生成物が存在しないかを確認するため, X線 回折試験を行った. 圧縮試験に用いた円柱試験体並びに水 和測定に用いた角柱試験体を利用し試料を採取した. 圧縮 試験破壊後，ほぼ中央付近から極微量の破片を採取し，水 和進行測定と同様，アセトンを用いて水和停止させた. 角 柱においても同様に行った。 その後, 水和停止させた破片 をすり錸により粉末状にし，その一部を試料として用いた。 $\mathrm{X}$ 線回折装置を用いて定性的に成分を分析しており，今回 は定量評価までは行っていない. 照射角度を変化させて成 分の特定を行った。

\section{3. 連続乾㷄における実験結果（シリーズ 1.2）}

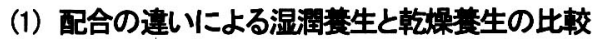
(シリーズ 1)

\section{a) 水和挙動}

図-1 (a) は水中養生環境下における配合の違いによる水 和の進行を表した図である.これより高水セメント比であ る $0.40 \mathrm{~W}$ と $0.50 \mathrm{~W}$ では水和挙動並びに水和がある程度進 行した材齢 91 日における水和率 (結合水量) はほとんど 変わらない.つまり, 外部からの水分供給が十分であれば 水和反応は阻害されず，良好な水和反応を起こし，限界ま で水和するといえる. 一方で低水セメント比である 0.25 や 0.30 においては外部から水分の供給があるにも関わら ず, 水和反心淮行しない. 一般的に完全水和に必要な水 セメント比は 0.27 程度であるが, 0.30 程度でもセメント粒 子の配置を考えたときには, 非常に緻密な構造となるため 水和生成物の生成できる空間が少ないことならびに水分 の浸透が内部までは起こりにくいため水和に必要な水分 が不足したといえる.一般的に水和反忘は非常に長い期間 継続するとされているが, 本研究で使用した試験体の大き さから考えると材路 28 日程度で水和抑制されることも考 えられる。

図-1 (b) は乾燥養生下での水和進行を示したものである。 乾燥養生に拉いては水セメント比によらずほぼ一定の水 和率に収束していることが分かる.このことから水セメン 卜比が低いほど乾燥養生における水和反忘への影響は低 減されるといえる. このことは反応生成物の析出できる空 間的な問題が大きな原因になると考えられるが, 本研究の 中では断言できないため今後検討していく予定である. 高 水セメント比では自由水の逸散量は多量であるために水 和進行が抑制されると考えられる。

\section{b) 内部絸樴棤造}

図-2 は材齢 56 日における水中養生と乾燥養生における 内部組織構造を示している. 各水セメント比における乾燥 盖生を行った試験体( $0.25 \mathrm{D}, 0.35 \mathrm{D}, 0.50 \mathrm{D})$ と水中養生を行っ た試験体 $(0.25 \mathrm{~W}, 0.35 \mathrm{~W}, 0.50 \mathrm{~W})$ とを比較すると乾燥養生を
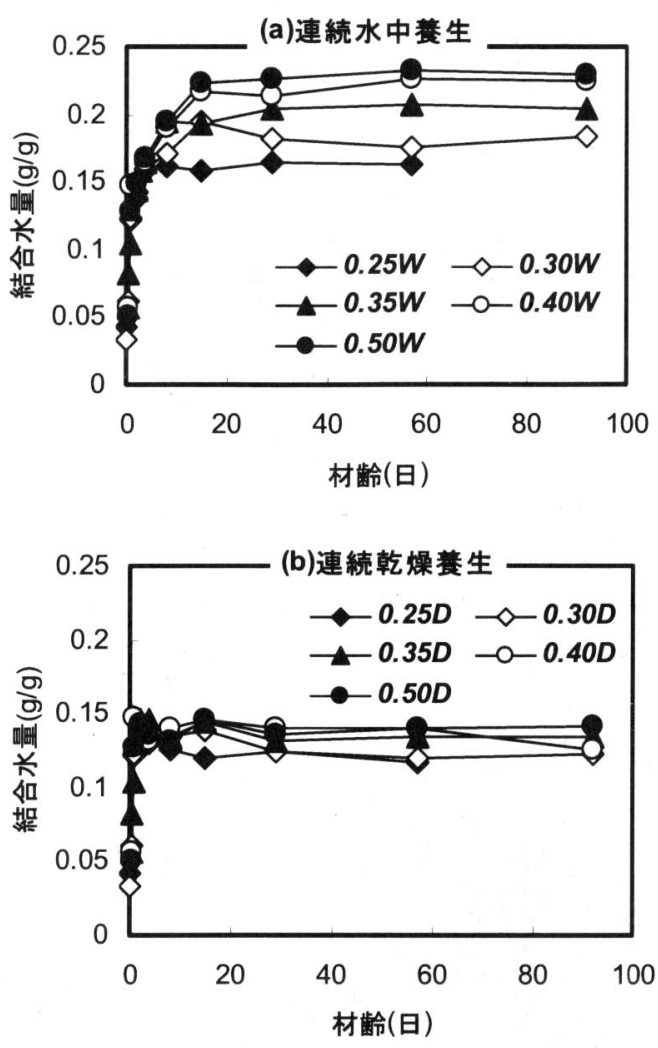

图-1 配合と環境の違いによる水和挙動の相違 (シリーズ 1)

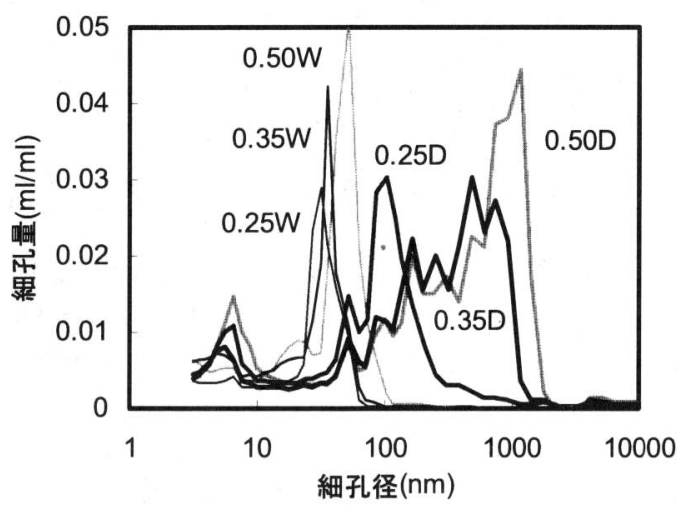

図-2 配合と環境の違いによる内部組織構造の相違 (シリーズ 1)

行うことにより非常に粗大な空隙を残存していることが 分かる. これは水和阻害により緻密化できなかった弊害と いえる. また, 水セメント比ごとに比較すると, 低水セメ ント比ほどピークを示す径の大きさが小さくなっている. 


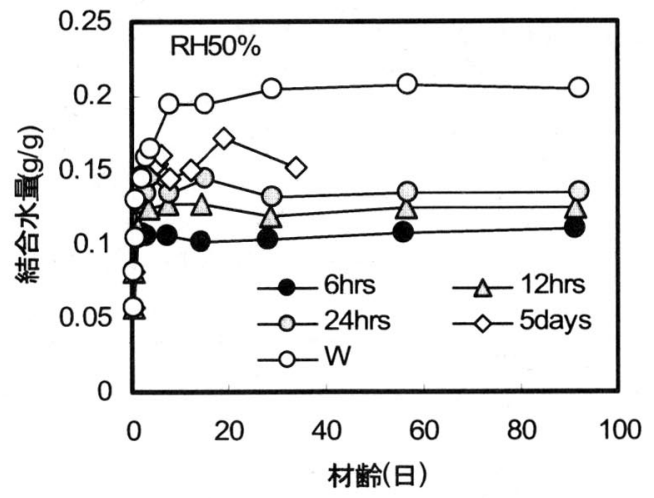

図-3 環境の違いによる水和挙動の相違

$$
\text { (シリーズ 2) }
$$

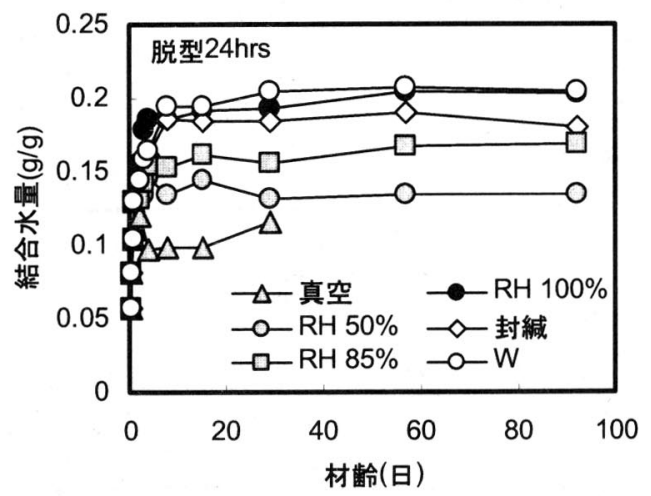

図-4 環境の違いによる水和挙動の相違

$$
\text { (シリーズ 2) }
$$

これは低水セメント比では末水和状態におけるセメント 粒子の配置の問題において，その空間の小さいことが起因 しているといえる. 水セメント比が高いほど大きな径が多 量に残存してしまっており，強度や耐久性に大きな影響を 与えていることが読みとれる.この傾向は乾燥養生で特に 顕著であるが, 水中養生 ${ }^{13)}$ でも同様であるといえる. 水中 養生下での水セメント比による相違点は, 水セメント比が 高いほど極微細径（ここでは $20 \mathrm{~nm}$ 程度以下）の空隙が多 く存在している.この理由については現在分かっていない が，抒そらく水セメント比が高いほど水和反応はしやすい 状態となりほぼ完全な水和反応が起こると仮定するとあ る径以下の空隙が残存し連結しや寸くなるといった反応 生成物が析出しうる空間の問題に起因しているのではな いかと考えられる.

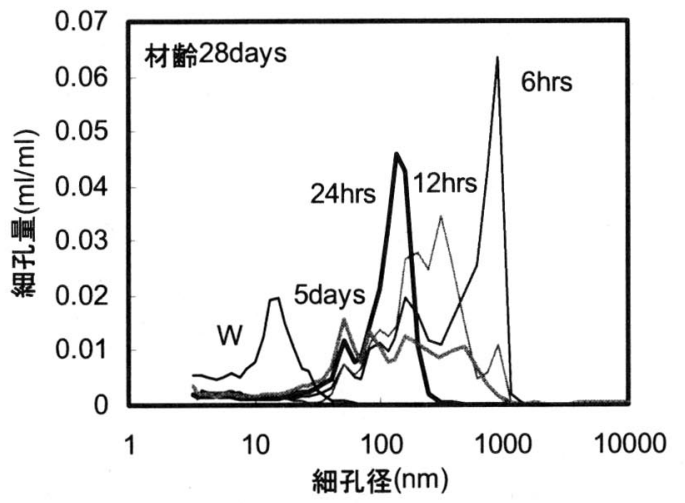

图-5 環境の違いによる内部組織構造の相違 (シリーズ 2)

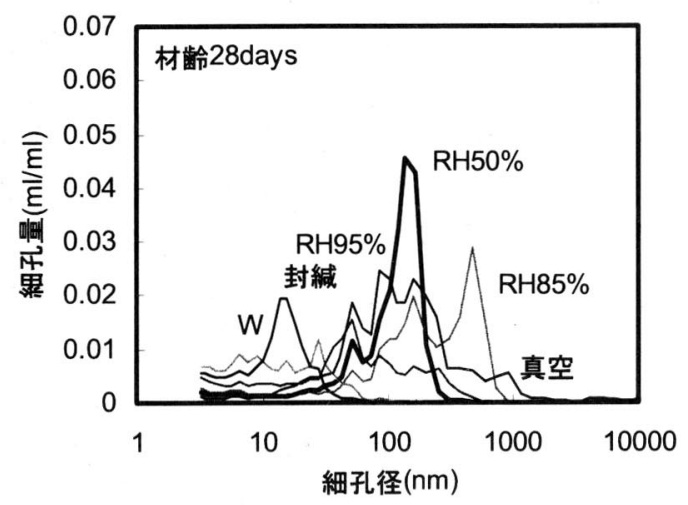

図-6＼cjkstart噮境の違いによる内部組織構造の相違 (シリーズ 2)

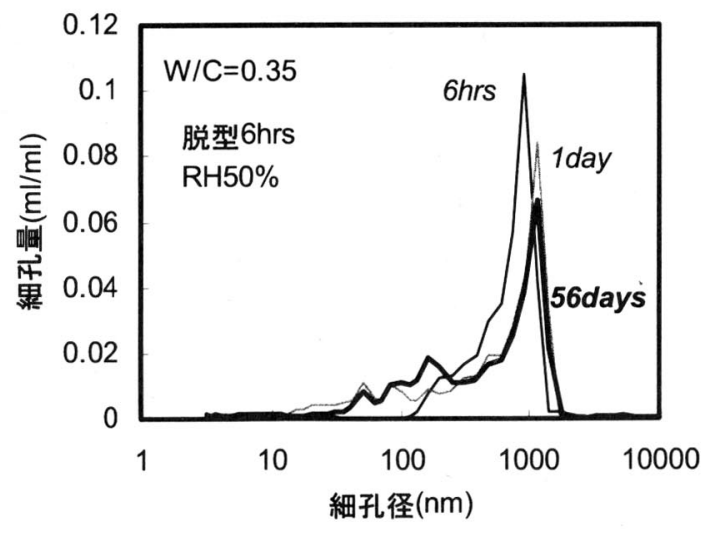

図-7連続乾燥養生における材齡の進行と内部組織構造 の変化 


\section{（2）脱型時期と環境の連いによる相違(シリーズ 2)}

\section{a) 水和挙動}

図-3 は脱型時期の違いによる水和挙動の相違を示して いる. この図より長期型枠存置した試験体ほど水和停止が 遅くなり水和停止時の水和率が高いということが分かる. つまり脱型時期の違いは水和停止時期に大きく影響を及 ぼすといえる.一方, 図-4 は環境条件の違いによる水和挙 動の相違を示している. なお，脱型時期は 24hrs で一定で ある.これより乾燥環境が厳しい真空養生や RH50\%にお いては早期に水分逸散による水和阻害が発生し，見かけ上 水和停止してしまうことがわかる.このことから外部環境 の違いは水和停止時の水和率に大きな影響を及ぼしてい るといえる. なお, 結合水量の若干の変動は試験体からの 切り出しならびに試験体間の誤差が含まれると考えられ る. また，炭酸化の影響も考慮されるが本研究では取り扱 わないこととした。

\section{b) 内部組䋨構造}

前述したとおり，水和反応と内部組織構造は密接な関係 あることから水和が停止した場合は長期材齢において粗 大な空隙を残存するといえる. 本研究においても, 脱型時 期や養生環境の相違により厳しい環境では粗大な空隙を 残存している結果が得られた. 図-5,6にそれぞれ脱型時期 の相違，環境条件の相違による細孔径分布を示す，なお， 図は材齢 28 日における結果である. それぞれ特徵的なこ とは, 脱型時期の違いによる内部組織構造の形成は，早期 脱型したものほど粗大な空隙を残存している．また，養生 環境の違いによる内部組織構造の形成は乾燥度の高いも のほど粗大な空隙を残存している. しかし，どちらかとい うと乾燥度の影響はあまり顕著ではなく, 脱型時期の影響 が大きいように見られる.このことから，脱型時期により 残存する粗大空隙の径が決定され，その量は外部環境の乾 燥度により決定するといえる。

次に材歯に伴う内部組織構造の変化を調査するために, 一例として図-7に脱型時期が 6 時間後で湿度 RH50\%の環 境で養生した細孔径分布の経時変化を示した. 一般的に水 分の供給が十分な環境では材粈とともにピーク径とその 量が減少していき緻密化する ${ }^{14}$. ᄂかし，乾燥環境下にお いては図に示したとおり, 水和停止後にはピーク径での量 の減少は起こるものの径の変動は見られない.このように 総細孔量の減少が一般的な緻密化ではなくピーク径は変 化せずにその量だけが减少するという現象が見受けられ た.この現象は脱型時期の違うものでも確認できた. これ はこの空隙領域内に含まれていた水分は完全に消費また は乾燥により逸散してしまい，不飽和領域が形成されてい るものだと考えられる.

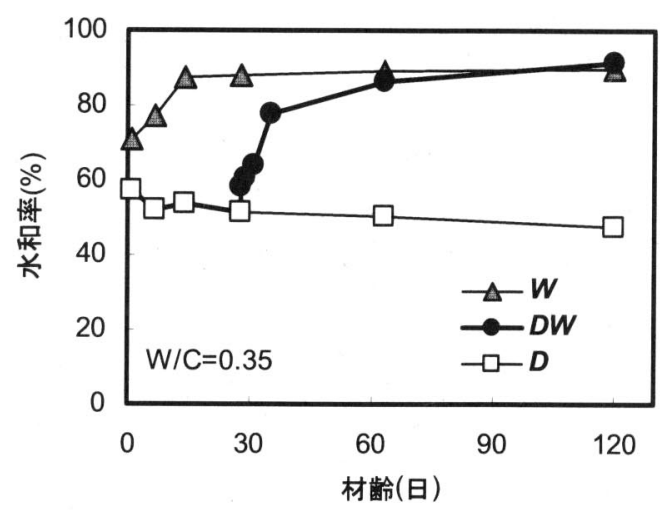

図-8 水分再供給後の水和挙動(W/C=0.35)

$$
\text { (シリーズ 3) }
$$

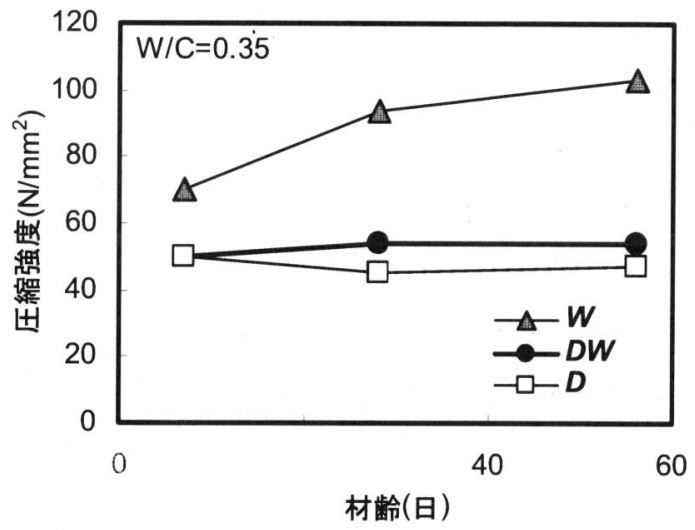

図-9 水分再供給後の圧縮強度発現性 $(W / C=0.35)$

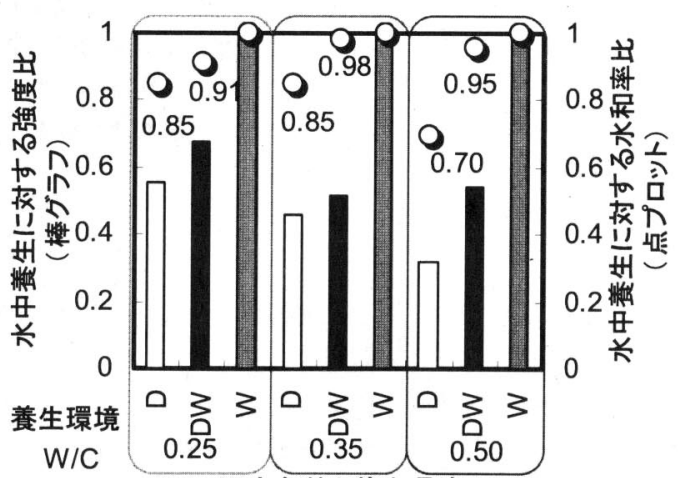

配合条件と養生環境

図-10 配合と養生環境の異なった試験体の水中養生に対 する圧縮強度比と水和率比 


\section{（3）連続乾燥による整害}

以上より連続的な養生を行った結果を以下にまとめる.

\section{a)水和反応に関して}

連続的な水中養生環境下では水和反応は促進するが，低 水セメント比では内部水分不足を引き起こし, 水分の供給 があるにも関わらず水和停止してしまう。一方，連続的な 乾燥養生環境にある場合には水和反忘は一時的に停止し てしまうことが分かった. 水セメント比に関しては環境の 影響は低水セメント比ほど水和反応に影響を与えていな いといえる. また, 脱型時期に関しては早期脱型するほど 早期に水和停止し，養生環境に関しては湿度が低いほど低 水和率で水和停止するといえる。

\section{b)内部絸織槽造二関して}

連続的な水中養生環境下では水和の進行つまり材齢の 経過とともに緻密化していく。一方，連続乾燥環境下では 水和の停止とともに粗大空隙を残存したまま組織形成さ れる. その形成過程は，脱型時期がピーク径を決定し乾燥 環境条件がその量を決定していると考えられる．また，材 齢の経過とともにピーク径の量だけが減少するといった 緻密化とは異なった現象が起こることが分かった。

\section{4. 水分再供給の実験結果(シリーズ 3)}

\section{（1）水和挙動}

図-8 は材齢 120 日までの $\mathrm{W} / \mathrm{C}=0.35$ における水和挙動 を示したものである. 前述したとおり水中養生は水和が促 進されており，乾燥養生では水和停止していることが分か る. また，水分を再供給した試験体においては水分の供給 直後から水和反応が起こり，水中養生を行っていた試験体 と同程度の水和率まで回復することが分かる.このことは 他の水セメント比の試験体についても同様の傾向を示し たことから連続乾燥下で養生した試験体は一時的に水和 停止しているものであり完全停止したのではないといえ る. また，外部からの水分の供給があった場合には水和反 応は再び起こることが分かった。

\section{（2）圧縮強度}

図-9はW/C=0.35における圧縮強度の発現を示したもの である. 圧縮強度の測定は試験時の内部含水状態の影響を できるだけ取り除くため，各養生槽から取り出した試験体 を 30 分程度大気に放置してから試験を行った． 圧縮強度 は内部含水率が大きく影響すると考えられるが，今回は大 気への放置並びに比較の対象を DW とW を主とし，両者 とも水中養生後の試験であるため比較することは可能で あると考えた. 材齢 56 日において水和進行を示した図-8 においてはほぼ水和率は回復しているにも関わらず，図-9 に見られるように圧縮強度は水分を再供給しても発現し

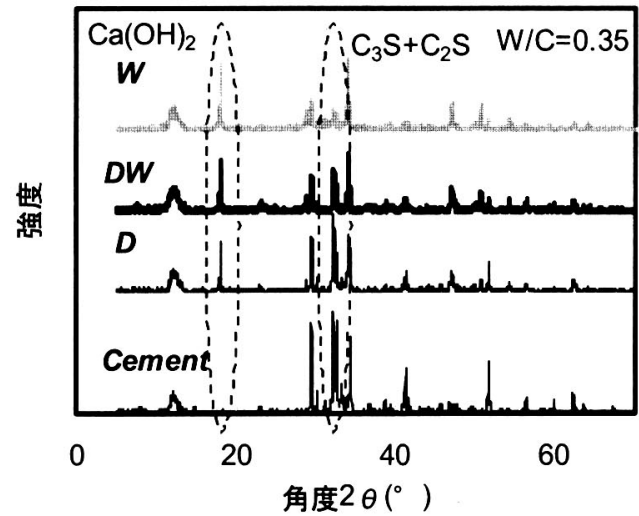

図-11 養生環境の違うセメント硬化体の $\mathbf{X}$ 線回折試験の 結果 $(\mathbf{W} / \mathrm{C}=\mathbf{0 . 3 5})$

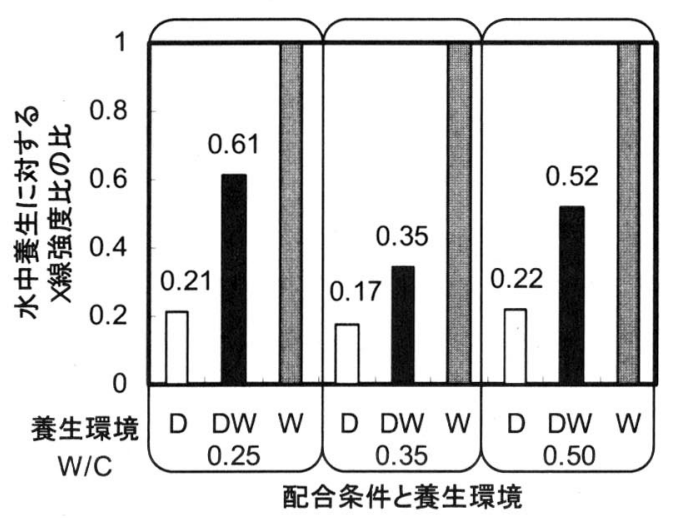

図-12 未水和物と水和生成物との $\mathrm{X}$ 線強度比の水中盖生 に対する比の比較

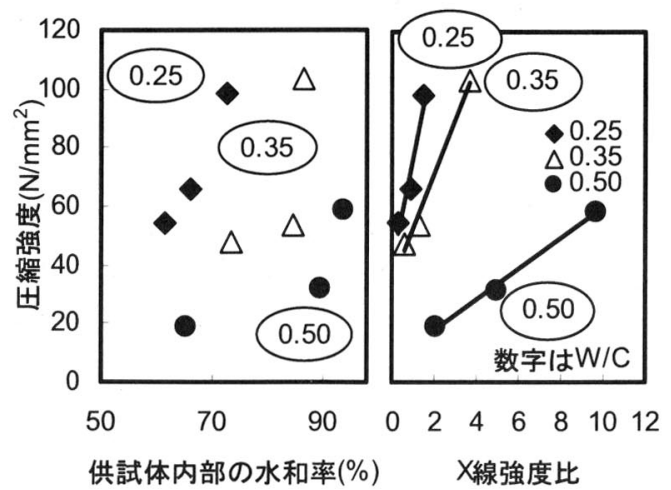

图-13 各水セメント比における圧縮強度と供試体内部の 水和率, $\mathbf{X}$ 線強度比の関係

ないことが分かる.このことをさらに考察するために水セ 
メント比を三種類として行った圧縮強度の発現率と圧縮 試験後に行った供試体中心部から採取した試料における 水和反心率を調查した結果を图-10 に示寸，なお，水和反 応率に関しては, 供試体中心部之供試体縁から数 $\mathrm{mm}$ での 結果を比較したところ，ほぼ同程度であったので供試体中 心部の值を採用している. 圧縮強度, 水和率ともそれぞれ の水セメント比における連続水中養生での試験体を 1 とし てその比率で示しており, 前者を棒グラフ, 後者を点プロ ットで示している.これより, 試験体内部における水和反 応は水分を供給することによって反応を再開し連続水中 養生した試験体とほぼ同程度まで水和回復するといった 図-8に見られた結果と同様の結果が得られた.しかし，圧 縮強度に関しては図-9 で示した傾向と同様にどの水セメ ント比においても連続水中養生と同程度までは回復せず, 6 割程度しか発現していない. そこで水和回復により圧縮 強度回復が見られない原因を詳細に調査するためにセメ ントペーストの圧縮強度に与える影響を考慮して(1)水和 生成物, (2)空隙分布を調查した.

\section{（3）水和生成物と空隚が圧縮強度に与える影需 \\ a) 水和生成物}

材齢 56 日後における未水和物と水和生成物との関係を 調べるために X 線回折を用いた分析を行った. 図-11 は $\mathrm{W} / \mathrm{C}=0.35$ における X 線回折の結果であり, 比較のために 反応前のセメント単体の結果も付設した. 図より未水和セ メントでは確認できない反応生成物 $\mathrm{Ca}(\mathrm{OH})_{2}$ が, 反忘した セメントでは測定角度 $18^{\circ}$ 近傍で確認できる. また, 反応 後のセメントである乾燥養生(D), 水分再供給(DW), 水中 養生(W)の間では波形には大きな差が見られるもののピー クを示す角度に変化は見られない.このことは異なった水 和生成物が生成されていないことを意味している. そこで, 末反応鉱物 $\left(\mathrm{C}_{3} \mathrm{~S}\right.$ と $\left.\mathrm{C}_{2} \mathrm{~S}\right)$ の強度と水和生成物 $\left(\mathrm{Ca}(\mathrm{OH})_{2}\right)$ の強 度の比をとり未水和物の反忘度の違いを比較した. これは この X 線回折で得られるデータが定量的なものでないこ とから末反応鉣物は反応後, 反応生成物に変化することを 利用して，その比をとることで水和度合いを比較すること を試みたものである. 利用したデータは $\mathrm{Ca}(\mathrm{OH})_{2}$ では前述 した $18^{\circ}, \mathrm{C}_{3} \mathrm{~S}$ と $\mathrm{C}_{2} \mathrm{~S}$ は $32^{\circ}$ 近傍を用いている. 測定結果か ら読みとったデータを基に未反応鉱物と水和生成物の $\mathrm{X}$ 線強度比率を算出し, その結果を水中養生に対する比率で 示したのが図-12 である.この比率が高いほど未反応鉱物 の残存量が少なく反応生成物が多いものと仮定すること で反応度が高いと評価する.DWにおける反度度はD と比 較寸ると明らかに高くなっており反応が進行していると いえる. しかし前述した水和率がほぼ等しい DW とW の 両者において，どの水セメント比に执ても DW はW の 5 割程度しか反応していない.この反応度の違いは他のク リンカー鉣物が水和したものか; あるいは水和生成物自体

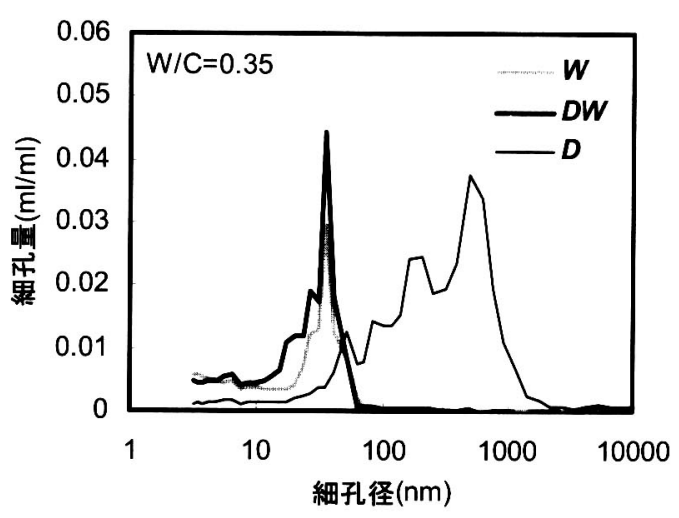

図-14 水分再供給した環境における内部組織構造 (シリーズ 3)

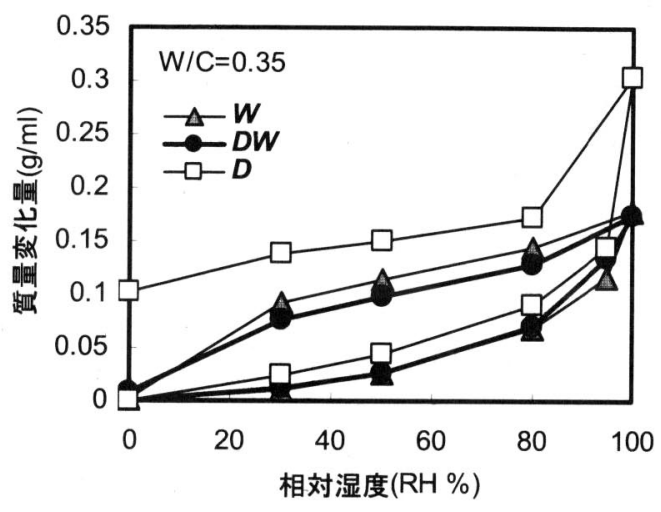

図-15 等温吸脱着試験の結果 $(W / C=0.35)$

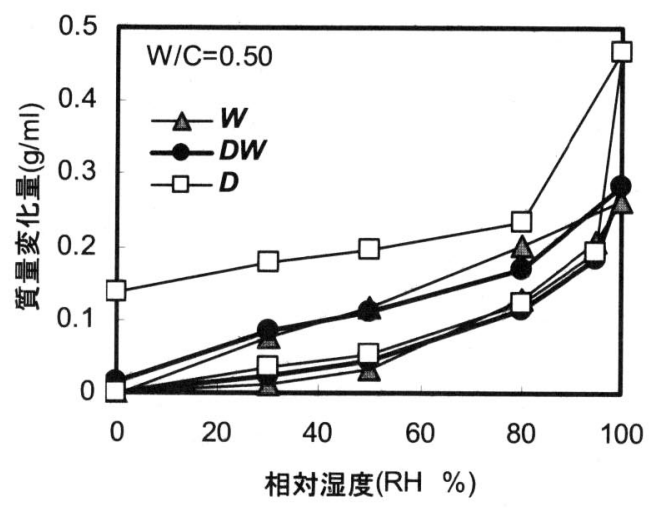

図-16 等温吸脱着試験の結果 $(W / C=0.50)$

の組成が異なることなど考察できるが, 現在のところわか っておらず引き続き調査を行っている.

そこで, 図-13 にそれぞれの水セメント比におけるる供試 
体内部の水和率と圧縮強度の関係, 並びに $\mathrm{X}$ 線強度比と圧 縮強度の関係を示した. 強熱減量法で測定した供試体内部 の水和率と圧縮強度には相関性が見られない.しかし，X 線強度比と圧縮強度の関係においては水セメント比ごと に一定の相関性が得られた. このことは， $\mathrm{C}_{3} \mathrm{~S}$ と $\mathrm{C}_{2} \mathrm{~S}$ の反 応が強度発現へ大きな影響を及ぼしているといえるとと もに一度乾燥履歷を受けた硬化体の再水和反応は連続的 な水中養生とは異なっていることが示唆できる. また, 強 熱減量法による水和測定と X 線回折を用いた反応度が異 なっており，乾燥の履歴を考慮する必要があるといえる．

\section{b) 空隌分布}

材齢 56 日における水銀圧入式ポロシメータを用いた空 隙分布の測定結果の一例を図-14 に示す。これより, 乾燥 養生と比較して水分再供給した試験体は緻密化している ことが分かる. また，その分布は水中養生を行った試験体 とほぼ同様の分布をしているといえる．しかし，ピーク径 における量とその近傍の径における空隙量が若干異なっ ており，初期におけりる乾燥が水中養生とは異なった細孔径 分布を作ると考えられる. これは前述の水和反応の相違や 水和生成物の析出できる物理的空間によるものと考えら れ，現在調査を進めている. しかし現段階においてこの極 微量の細孔径分布の相違も圧縮強度に影響を及ぼしてい ると考えている.このような結果は本研究において行った 全ての水セメント比において得られたことを付記する.

\section{c）供試体のひび割れの影霎}

圧縮試験に用いた試験体を目視で外部観察を行っ たところ，50×100mm の試験体においてはいずれの 養生環境においても目立ったひび割れなどは発見で きなかった。しかし，供試体サイズを大きくした $100 \times 200 \mathrm{~mm}$ の試験体では乾燥収縮が原因となるひ び割れの発生が認められた。これは試験体サイズが 大きくなることで拘束力が大きくなり発生したもの と思われる，サイズの違いによりさらに強度が発現 しなかったことから，乾燥収縮等により発生したマ イクロクラック等が欠宿部となり圧縮強度に影響し ていると考えられる。またこの大きな試験体におい て, 水分再供給(DW)の試験体においてはひび割れの 発生後, ひび割れを充填している白濁色の物質を検 知できた。この物質並びに水和反応に関しては現在 研究を進めているところで，末解明である.

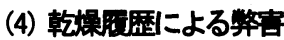

以上より乾燥後水分再供給を行った結果をまとめる.

\section{a) 水和反応に関して}

強熱减量法による水和測定では乾燥履歷後の試験体に 水分を再供給することで再水和反応により水和度が回復 することが分かった．しかし，X線回折を用いた結果では 水和生成物と未水和物との強度比が必ずしも一致せず未
水和物が同程度まで水和し $\mathrm{Ca}(\mathrm{OH})_{2}$ を析出しているとは考 えられない。

\section{b) 空裳分布に関して}

水分を再供給することで空隙構造は緻密化し, 水中養生 と同様の分布を示す．しかし，ピーク径が同じであっても その周辺の径における細孔量が異なっている.このことか ら乾燥履歷が内部組織構造に影響を与えているといえる.

\section{5. 内部組織楛造の一考察}

これまでの結果より外部環境作用により内部組織構造 は大きく変化するといえた. そこで，その内部組織構造を 異なった角度からとらえ，耐久性に及ぼす影響を評価する ために等温吸脱着試験を試みた。等温吸脱着試験は乾燥・ 湿潤過程における空隙飽和度の履歷挙動を測定するもの であり, 今回は石田ら ${ }^{15}$ の試験方法を参考に以下に示寸方 法で測定を行った.

試料は $5 \mathrm{~mm}$ 角程度の小さなものを使用した．また，試 料の質量変化がほぼ平衡に達するまでの期間は実験結果 より 2 日程度であると確認できたため湿潤・乾燥過程とも 平衡時期までの時期を 2 日とした。

i 湿潤過程 : 真空脱気した試料を RH $0 \%$ とし質量を測 定し，その後温度を $20^{\circ} \mathrm{C}$ に保持した状態で湿度を RH30,50,80,95,100\%と変化させて質量を測定した．なお， RH100\%は試料内部が水で満たされた状態であり，水を入 れた容器に試料を入れ真空脱気することで試料内部の空 隙まで水を充填させることとした.

ii )乾燥過程 : 湿潤過程と同様に湿度を RH100,80,50, $30,0 \%$ と順次低下させて質量変化を測定した.

その結果の代表例として水セメント比 0.35 と 0.50 の結 果をそれぞれ図-15, 16 に示す. 図より連続乾燥(D)では乾 燥過程においてループが閉塞しないことがわかる.これは 末水和セメントの粒子が湿潤過程において水分の供給を 受けたため再水和反匛を起こし, 水和による質量変化と空 隙の閉塞によるトラップ水の発生によるものと考えられ る. 一方水中養生(W) と水分再供給 $(\mathrm{DW})$ ではループは閉塞 する. しかし，両者の乾燥過程における挙動が異なってい ることが分かる．水分再供給(DW)では RH100\%から RH $80 \%$ 一の移行過程で水中養生(W)に比べ質量减少量が 大きい.このことは空隙の連結性において異なった性状を 示しているといえ，液体である水が出て行きやすい構造に なっているといえる. つまり，耐久性を考えると W に比 ベ DW は劣っている細孔組織構造が形成されているとい える. このような観点から考察しても乾燥履歴は而久性に も大きな影響を及ぼすといえる。 


\section{6. まとめ}

本研究によって得られて知見を以下にまとめる.

（1）連続的に水分が供給される環境では水和反応は促進 され内部組織構造は緻密化する. しかし, 配合上水分 の不足している状態では水和反応は停止し内部組織 構造はそれ以上緻密化しない。

（2）初期材龄から連続的に乾燥の影響を受ける環境では 内部の水分が不足することから一時的に水和反応は 停止してしまう. それに伴い内部組織構造も粗大な空 隙を残存したままの粗な空隙構造を形成する. また, 脱型時期がピーク径を決定し乾燥状態がその量を決 定しているといえる.

（3）一度乾燥履歴を受けた後に水分を再供給すると水和 反応は再び起こり, その後連続的に水分を供給するこ とで, 強熱減量法で測定した場合水中養生した水和率 と同程度まで回復するという結果が得られる. しかし， $\mathrm{X}$ 線回折を利用した反応物の調査を行うと反応度が 水中養生した場合とは異なっており, 水和反応に相違 が生じていると考えられる. また，再水和反忘に伴い 内部組織構造は緻密化しているがピーク径周辺の細 孔量が異なっており内部組織構造も相違が生じてい るといえる.

（4）養生環境による圧縮強度を比較すると水分再供給し た場合, 水中養生の半分程度しか強度発現しておらず， 水和反応と内部組織構造の相違が強度に大きな影響 を与えていると考えられる。

(5) 等温吸脱着試験による内部組織構造と耐久性一の影 響を調查したところ，乾燥履歴は耐久性に影響を与え ると考えられる.

謝辞: 本研究を行うにあたり元千葉工業大学大学院 高羅信彦氏, 元芝浦工業大学卒論生長谷川博之氏に 実験に関して多大なご助力をいただきました.また， 東京大学生産技術研究所岸利治助教授並びに加藤佳 孝講師に多くのご助言をいただきました。ここに記 し, 感謝いたします. 最後に東京大学生産技術研究 所魚本研究室のみなさまのご助力にも感謝いたしま す. なお, 本研究費の一部は平成 12 年度科学研究費 補助金基盤研究(A)(2)課題番号 12305029 (代表 : 魚 本健人）によったものであることを付記する.

\section{参考文献}

1) 土木学会: 平成 11 年版コンクリート標準示方書 [施 工編］一耐久性照查型一, 1999.
2）たとえばセメント協会: コンクリート専門委員会報告, F-38, 初期の乾燥がコンクリートの諸性質に及ぼす影響, 1985.7.

3) 森本丈太郎, 魚本健人: 初期高温養生したポルトラン ドセメントの水和に関する研究, コンクリート工学年 次論文報告集, Vol.17, No.1，pp.651-654，1995.

4) 永松静也，竹田吉紹, 佐藤嘉昭 : 乾燥を受けるセメント硬化 体の水和の進行を表す式，日本建築学会構造系論文報告集， No.361, pp.21-30, 1986.

5) 佐伯竜彦, 米山紘一, 長滝重義: 初期養生以降のセメントの 水和の影響を考慮した中性化進行予測, 土木学会論文集 No.508/V-26, pp.33-44, 1995.

6) 伊代田岳史, 高羅信彦, 魚本健人 : 初期養生時に乾燥を受け るセメント采硬化体の水和反応と水分逸散特性，コンクリー 卜工学年次論文集, Vol.22, No.2, pp.703-708, 2000.

7) 伊代田岳史, 魚本健人 : 初期材龄における乾燥履歴がセメン 卜硬化体の水和反忘と強度発現に与える影響, セメント・コ ンクリート論文集 , 55 巻, pp.116-1121，2001.

8)伊代田岳史, 魚本健人: 乾燥による水和停止後の水分再供給 による水和挙動, 第55回セメント技術大会講演要旨, pp.16-17, 2001.

9）伊代田岳史，魚本健人 : 早期脱型による乾燥と水分の再供給 がコンクリートの内部組織構造に与える影響, コンクリート 工学年次論文集, Vol.23, No.2, pp.787-792, 2001.

10) Cong $X$. and Kirkpatrick,R. J. : Effects of the temperature and relative humidity on the structure of C-S-H gel, Cement and Concrete Research, Vol.25, No.6, pp.1237-1245,1995

11) Gallé, C. : Effect of drying on cement-based materials pore structure as identified by mercury intrusion porosimetry $\mathrm{A}$ comparative study between oven-, vacrum-, and freeze-drying, Cement and Concrete Research, Vol.31, No.10, pp.1467-1477,2001.

12）コンクリートの試験・分析マニュアル, 日本コンクリートエ 学協会, 2000.

13) Cook R. A., Hover K. C. : Mercury porosimetry of hardened cement pastes, Cement and Concrete Research, Vol.29, pp.933-943, 1999.

14）セメント協会: わかりやすいセメント科学, 1993.

15）石田哲也，CHAUBE R.P., 岸利治, 前川宏一: 任意の乾湿 繰り返しを受けるコンクリートの含水状態予測モデル，土木 学会論文集, No.564/V-35, pp.199-209, 1997.

(2001.11.22 受付) 


\section{EFFECT OF DRYING CONDITION AT EARLY AGE ON MICROSTRUCTURE OF HARDENED CEMENT}

\section{Takeshi IYODA and Taketo UOMOTO}

Curing is very important for its good performance for early age. However, many reports suggest that removal of formwork is too quick for early age. Upon been exposed to the drying conditions, the cement hydration is not able to progress. In this research, the aim is to find out the effect of drying. When cement hydration was temporarily stopped, there were many large pores remaining after drying. On the other hand, when moisture was re-supplied into the specimens after drying, cement hydration was restarted and the remaining large pores became smaller. However, the compressive strength could not be recovered. The reason is that re-supplying of moisture will produce different hydration products and microstructures and also there are some cracks in the specimens. 